\title{
АНАЛІЗ РОЗВИТКУ РУХОВИХ ЗДІБНОСТЕЙ СТУДЕНТОК ЗАКЛАДІВ ВИЩОЇ ОСВІТИ ЗАСОБАМИ СПОРТИВНИХ ІГОР У ПРОЦЕСІ СЕКЦІЙНИХ ЗАНЯТЬ
}

\author{
Рибалко П. Ф., Самохвалова І. Ю.
}

\section{ВСТУП}

Стан здоров'я студентської молоді безпосередньо впливає на працездатність і продуктивність праці, моральний клімат у суспільстві, а також відображає спосіб і якість життя.

Новітні вимоги до системи вищої освіти потребують їі переходу від застарілої моделі до неперервної освіти (освіти впродовж життя). Це передбачає зміни у структурі освітнього процесу, технології навчальнометодичного забезпечення, застосуванні експериментальних методів тощо.

Збереження здоров'я нації - об'єктивна необхідність сьогодення, тому зусилля молодої дівчини повинні бути спрямовані на відновлення втрачених резервів здоров'я, збереження та продовження здорового роду, забезпечення високої соціально-творчої активності та професійної діяльності ${ }^{1}$.

Однією 3 інноваційних моделей розвитку вищої освіти $\epsilon$ неформальна освіта. Завдяки неформальній освіті людина здатна подолати суперечності між психологічними і соціальними потребами: здійснити пошук соціальних ресурсів для задоволення власних потреб; забезпечити особистісно значущі цінності, цілі та прагнення; гармонізувати взаємодію з оточенням.

Важливий напрям діяльності вищих навчальних закладів - пошук нових форм зміцнення здоров'я студенток у процесі їх навчання та виховання, упровадження здоров'язбережувальних технологій у навчально-виховний процес, охоплення студенток заняттями фізичною культурою і спортом, формування в них умінь оздоровчої діяльності. ${ }^{2}$

Вихляєв Ю. Інноваційні технології фізичного виховання студентів : навчальний посібник. Київ : КПІ ім. Ігоря Сікорського, 2018. 543 с.

2 Іваненко Т. Формування позитивно ціннісного ставлення студенток університету до оздоровчої діяльності : автореф. дис. ... канд. пед. наук: 13.00.07. Київ, 2011. 16 с. 
Неформальна освіта має потенціал забезпечення базових потреб особистості в самопізнанні, саморозкритті, саморозвитку без виключення із системи соціальних взаємодій з іншими.

Неформальна фізкультурна освіта може розвинути потреби студенток повсякденно займатися фізичними вправами, дбати про власне здоров'я та здоров'я оточення. Це необхідна умова досягнення високих соціальних стандартів і реалізації професійних надбань.

Саме неформальна освіта може подолати суперечності між психологічними та соціальними потребами. Це відбувається завдяки тому, що комунікативна атмосфера не передбачає жорстких рамок, сприяє саморозкриттю, саморозвитку особистості.

Постає необхідність аналізу визначень поняття «неформальна освіта» для виділення його основних компонентів та глибшого розуміння сутності неформального навчання як сучасної форми задоволення освітніх потреб студентської молоді.

Для вирішення вищезазначених проблем ми пропонуємо використовувати особистісно орієнтований підхід до процесу занять, а саме надати студенткам змогу самим обирати вид спорту або рухової активності, якими вони би займалися на заняттях із фізичного виховання.

Переваги секційної форми організації фізичного виховання в тому, що у процесі занять у студенток формуються знання, практичні вміння, навички та потреби самостійно займатися фізичними вправами все життя. ${ }^{3}$

\section{1. Теоретико-методичні засади використання програми для розвитку фізичних якостей студенток закладів вищої освіти у процесі неформальної освіти}

Перед фахівцями постає необхідність пошуку, розроблення та впровадження інноваційних методик, які б, у свою чергу, найбільш позитивно впливали на стан здоров'я студентської молоді, фізичну підготовленість, фізичну та розумову працездатність, сприяли зростанню мотивації, формуванню звички до постійних занять фізичними вправами та спортом, а також до ведення здорового способу життя. ${ }^{4}$ Усе це в подальшій життєдіяльності сприятиме високій та продуктивній праці на обраному підприємстві, впевненості та самореалізації. Тому проблема вдосконалення фізичного виховання

${ }^{3}$ Кляп М. Інноваційні методи навчання у ВНЗ як інструмент інтернаціоналізації вищої освіти України. Вища освіта України. 2015. № 4. С. 45-53.

${ }^{4}$ Рибалко П. Сучасні технології збереження та відновлення здоров'я молоді в діяльності фахівця 3 фізичної культури. Вісник Чернігівського національного педагогічного університету імені Т.Г. Шевченка. Серія «Педагогічні науки». 2016. Вип. 136. С. 181-184. 
студентів i пошук шляхів покращення стану їхнього здоров'я $\epsilon$ актуальною.

Мета дослідження полягає в науковому обгрунтуванні, розробці й експериментальній перевірці програми для розвитку рухових якостей студенток закладів вищої освіти у процесі неформальної освіти.

Дослідження проводилось у два етапи.

На першому етапі (вересень 2017 р. - січень 2018 р.) проводився аналіз науково-методичної літератури за темою дослідження. Розглянуто особливості організації процесу фізичного виховання студенток, визначено мету та завдання дослідження, проводився відбір методів дослідження.

Проведено констатувальний експеримент, метою якого стало отримання первинної інформації про рівень функціонального стану і розвитку фізичних якостей студенток. У констатувальному експерименті взяли участь 75 студенток. На даному етапі проводилася розробка програми, спрямованої на розвиток рухових якостей у студенток. Основним завданням даного етапу дослідження було формування експериментальних груп.

На другому етапі (лютий 2018 р. - жовтень 2019 р.) проведено основний педагогічний експеримент із метою перевірки ефективності розробленої програми занять. Мета проведення експерименту полягала у визначенні впливу та порівнянні розробленої програми занять із традиційною програмою занять із фізичного виховання. За результатами констатувального експерименту було відібрано 46 студенток I курсу віком 16-18 років, які не мали достовірних відмінностей у досліджуваних показниках, i 3 них сформовано контрольну групу (далі - КГ), $\mathrm{n}=23$, та експериментальну (далі - ЕГ), $\mathrm{n}=23$. Студентки експериментальної групи займалися за авторською програмою на основі впровадження ігрових видів спорту у процесі секційних занять. Проведено аналіз i узагальнення отриманих результатів дослідження.

Відомо, що фізичне здоров'я - це рівень розвитку і функціональних можливостей органів і систем організму. Основу фізичного здоров'я становлять морфологічні та функціональні резерви клітин, тканин, органів і систем органів, які забезпечують пристосування організму до впливу різних чинників. Стан здоров'я студентської молоді критичний, 3 кожним роком погіршується, тому особливу увагу варто приділяти вивченню стану здоров'я студенток, від яких залежить майбутнє нашої нації.

У дослідженні взяли участь 75 студенток Сумського національного аграрного університету та Сумського державного педагогічного університету імені А.С. Макаренка. 
Тестування рівня стану фізичного здоров'я студенток проводилось за системою оцінювання фізичного здоров'я за методикою Г. Апанасенко. 5

У стані спокою вимірювалися такі показники: ЖЕЛ, ЧСС, АТ, маса тіла, довжина тіла, динамометрія кисті. Проводилося тестування у пробі Руф'є.

Вимірювалось ЧСС обстежуваного в положенні сидячи після 5 хвилин відпочинку (далі - ЧСС ${ }_{1}$ ), потім досліджуваний виконував 30 глибоких присідань, викидаючи руки вперед, за 45 с і одразу ж сідав на стілець. Проводився підрахунок ЧСС за перші 15 с після навантаження (далі - ЧСС 2 ), потім за останні 15 с із першої хвилини після навантаження (далі - ЧСС ${ }_{3}$ ).

Всі підрахунки виконувались за існуючими формулами, показники оцінювались у балах, за п'ятьма рівнями їхнього фізичного здоров'я: низький, нижчий за середній, середній, вищий за середній, високий. ${ }^{6}$

Результати досліджень констатувального експерименту 3 визначення стану здоров'я студенток показали, що 30,8\% студенток мають середній рівень, а більша частина респондентів мають нижче за середній рівень фізичного здоров'я - 39,4\%. Установлено, що у групі безпечного рівня здоров'я студенток першого курсу: високий рівень мали $0,6 \%$, вищий за середній - 3,1\%, інші 96,3\% студенток першого курсу перебувають за межами безпечного рівня: середній - 32,9\%, нижче за середній $-36,7 \%$, низький $-26,7 \%$ (рис. 1 ).

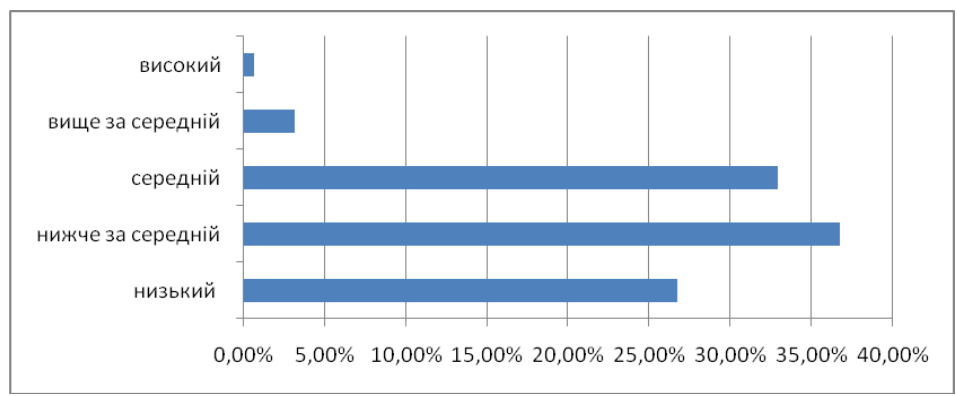

\section{Рис. 1. Результати дослідження показників рівня стану здоров'я студенток}

5 Апанасенко Г., Науменко Р. Экспресс-оценка уровня физического развития. Теория и практика физической культуры. 1988. № 4. С. 27-29.

${ }^{6}$ Кашуба В., Денисова Л., Усиченко В. Комп'ютерна техніка та методи математичної статистики : навчальний посібник. МОНУ, НУФВСУ. Київ, 2015. $212 \mathrm{c}$. 
Рівень соматичного здоров'я вивчався за такими показниками, як: індекс маси тіла, життєвий індекс, силовий індекси, індекс Робінсона, індекс Руф'є й обрахований індекс соматичного здоров'я досліджуваного контингенту.

Показник індексу маси тіла студенток першого курсу становить $23,45 \pm 0,19 \kappa \Gamma / \mathrm{m}^{2}$, життєвий індекс дорівнює 52,69 $\pm 0,58 \mathrm{мл} / \mathrm{\kappa}^{-1}$. Силовий індекс дівчат першого курсу $-45,73 \pm 1,03 \%$, індекс Робінсона $-87,05 \pm 0,41$ ум. од., індекс Руф'є $-9,71 \pm 0,26$ ум. од. Індекс соматичного здоров'я (далі - IC3) студенток становив 4,61 $\pm 0,26$ бали, показники нижче за середні.

Отримані результати оцінки стану здоров'я студенток свідчать про незадовільний рівень соматичного здоров'я студентської молоді.

Доведено, що необхідною умовою формування інтересу до навчальної діяльності $\epsilon$ надання студентам можливості проявляти самостійність та ініціативу. Науковці звертають увагу на той факт, що проблема мотивації до занять із фізичного виховання у студентської молоді актуальна і на етапі сьогодення. ${ }^{7}$

Існують внутрішні і зовнішні чинники, у яких є деякі розходження, що впливають на мотивацію до систематичного виконання фізичних вправ як засобу самовдосконалення у студентів.

Такі зовнішні чинники, як: відвідування змагань, поради викладачів, друзів, телебачення та преси, є відносно рівноцінними. У свою чергу, внутрішніми чинниками можна вважати знання, переконання, бажання і пошук причин, що заважають реалізувати свою мету.

Тому вивчення мотивів і рухових уподобань студенток до занять із фізичного виховання допоможе визначити засоби фізичного виховання, які сприятимуть зацікавленості та зростанню стійкої потреби до занять фізичними вправами та спортом у студентської молоді.

Для визначення мотивів, інтересів і ставлення студенток до занять із фізичного виховання нами була використана анкета, яка складалася 3 питань визначення мотиваційно-ціннісного ставлення студентської молоді до занять у сфері фізичної культури і спорту.

В анкетуванні взяли участь 150 студенток.

У процесі вивчення потреб студенток щодо видів рухової активності було встановлено, що з переходом від одного вікового рівня до іншого спостерігається зменшення кількості обраних ними видів спорту, що свідчить про недостатню сформованість потреби в заняттях певним

\footnotetext{
${ }^{7}$ Петренко О. Вивчення ставлення студенток економічних спеціальностей до занять з фізичного виховання. Молода спортивна наука Украӥни. 2014. Т. 2. С. 98-101.
} 
видом спорту. ${ }^{8}$ Студентки активно шукають ті види рухової активності, у яких вони можуть реалізувати свій потенціал. Це є підставою для розширення діапазону рухової активності та можливості корекції робочої навчальної програми.

Вивчення мотиваційно-ціннісного ставлення ${ }^{9}$ студенток до фізичного виховання дозволило виділити основні мотиви, що відображають це ставлення: фізичного вдосконалення, покращення стану здоров'я, повинності, суперництва, наслідування, спортивний та ігровий (рис. 2).

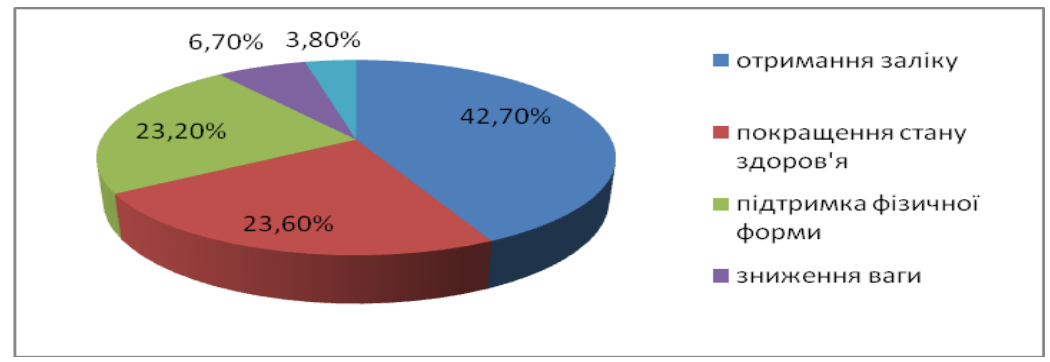

Рис. 2. Мотиви студенток щодо занять фізичними вправами

Отримані дані дозволяють уважати, що розподіл пріоритетів у цій сфері має велику схильність до мотиву повинності (42,7\%). Отримання заліку із предмета підміняе поняття «фізичне виховання».

Одним із головних мотивів для $23,6 \%$ студенток $є$ «покращення стану здоров'я». Варто зазначити, що даний мотив $€$ пріоритетним для контингенту з вадами у стані здоров'я.

Прагнення досягти високих спортивних результатів престижно для обмеженого кола студенток $(3,8 \%)$. Це свідчить про те, що можливості фізичного виховання як засобу підтримки працездатності ще не мають належної оцінки у студенток.

Турбота про свій фізичний стан не стала постійною потребою для більшості студенток, про що свідчить аналіз мотиву фізичного вдосконалення: підтримка рівня фізичної підготовленості - 23,2\%; зниження зайвої ваги $-6,7 \%$.

${ }^{8}$ Методика викладання навчальної дисципліни «Фізичне виховання» у закладі вищої освіти / Р. Харченко та ін. Педагогічні науки: теорія, історія, інноваційні технологіï. 2019. № 5. С. 183-195.

9 Захаріна Е. Формування мотивації до рухової активності в процесі фізичного виховання студентів вищих навчальних закладів : автореф. дис. ... канд. наук з фіз. вих. і спорту: 24.00.02. Київ, 2008. 27 с. 
Отримана інформація свідчить про невпорядкованість ціннісного ставлення студенток до фізичного виховання і спорту.

Спрямованість практичних занять на розвиток потреби студенток повсякденно займатися фізичними вправами, дбати про власне здоров'я i здоров'я оточення може не тільки радикально змінити їхню фізкультурну активність, але і загалом прищепити спортивний стиль повсякденної життєдіяльності.

У процесі соціологічного дослідження ми також з'ясовували, які форми занять із фізичного виховання найбільш цікаві та подобаються студенткам.

Для визначення рухових уподобань і форм проведення занять в анкеті на запитання «Яка форма проведення занять фізичною активністю Вам подобається?» 67,4\% студенток відповіли, що найкращою формою для них $є$ заняття за вибором спортивної секції, $10,7 \%$ уважають необхідними заняття 3 фізичного виховання, $21,9 \%$ самостійні заняття (рис. 3).

Можливість обирати вільно форму занять фізичною активністю свідчить про наявність у людини усвідомленого, активного інтересу до фізичного та психічного самовдосконалення.

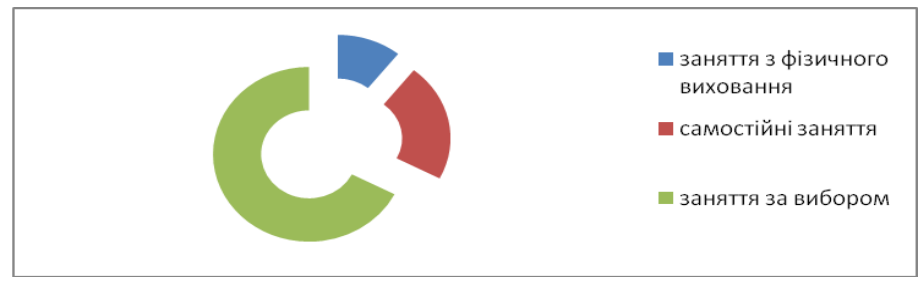

\section{Рис. 3. Мотивація студенток до занять фізичними вправами}

Під час визначення рухових уподобань студенток щодо занять фізичною культурою та спортом було виявлено (рис. 4), що серед найбільш популярних видів студентки назвали ігрові види спорту $42,8 \%$, а також заняття фітнесом - 30,6\%.

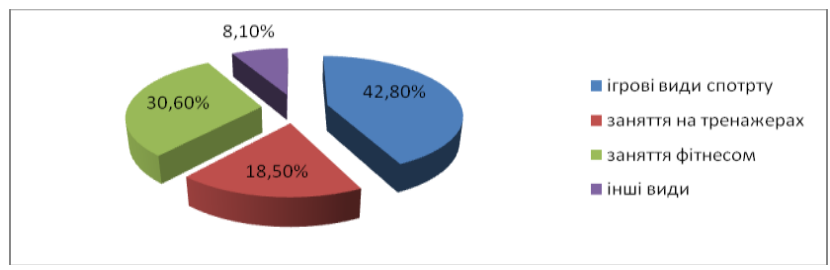

Рис. 4. Визначення пріоритетних форм проведення занять 
Результати дослідження мотиваційних інтересів і рухових уподобань студенток показали, що програми занять із використанням сучасних інноваційних видів рухової активності $\epsilon$ пріоритетними у студентської молоді.

\section{2. Обгрунтування й експериментальна перевірка програми для розвитку рухових якостей студенток закладів вищої освіти}

На основі результатів констатувального експерименту нами була розроблена програма розвитку рухових якостей студенток закладів вищої освіти.

Теоретичний розділ програми реалізувався через лекційні заняття, бесіди, диспути з елементами діалогу, був спрямований на формування світоглядної системи науково-практичних знань i позитивного ставлення студенток до занять фізичною культурою, до здорового способу життя.

Поєднання теоретичних і практичних занять дозволяє підвищити інтерес студенток до навчального процесу 3 фізичної культури, стимулює набуття навичок організації здорового способу життя, сприяє формуванню професійно-прикладних знань, умінь і навичок.

Практичний розділ реалізувався у формі практичних занять, на яких передбачалося освоєння студентками методик самоконтролю, самооцінки шляхом оволодіння різними компонентами (загальний фізичний розвиток, розвиток спеціальних фізичних i психічних якостей, зміцнення власного здоров'я).

Специфікою пропонованої програми визначено доцільність занять фізичними вправами на основі ігрових видів спорту (волейбол, баскетбол, настільний теніс), які сприяють активації обміну речовин, поліпшенню діяльності центральної нервової системи, забезпеченню адаптації кардіореспіраторної та інших систем організму до умов необхідної м'язової діяльності, прискорюють процес адаптації до професійної діяльності систем кровообігу й дихання, а також сприяють швидшому відновленню після фізичної втоми.

Заняття фізичними вправами на основі ігрових видів спорту впливають на організм з оздоровчою і тренувальною метою, причому оздоровча мета реалізується шляхом підвищення рівня розвитку фізичних здібностей (як загальних, так і спеціальних), формування i вдосконалення професійно значущих рухових умінь i навичок. Підвищення ж рівня фізичної підготовленості має вагомий ефект в оздоровленні й фізичному зміцненні організму студенток. ${ }^{10}$

10 Рибалко П., Харченко С., Матлаш В. Професійно-прикладна фізична підготовка студенток аграрного вузу що займаються в секції 3 футболу. Вісник Чернігівського національного педагогічного університету імені Т.Г. Шевченка. 2017. Вип. 149. С. 212-215. 
Вибір вказаних спортивних ігор зумовлений їхнім різноплановим впливом на організм студенток.

У дослідженні взяли участь студентки Сумського національного аграрного університету факультету агротехнологій - природокористування та факультету економіки і менеджменту, а також Сумського державного педагогічного університету імені А.С. Макаренка - природничогеографічного та фізико-математичного факультетів.

Респонденти (46 дівчат) були розподілені на дві групи: контрольну (КГ) та експериментальну (ЕГ), по 23 студентки в кожній.

Студентки контрольної групи займались фізичним вихованням за робочою навчальною програмою кафедр фізичного виховання, затвердженою вченою радою відповідних закладів вищої освіти. Студенткам експериментальної групи було запропоновано, окрім традиційних занять із фізичного виховання, відвідувати секцію спортивних ігор. Робота секції базувалась на використанні ігрових видів спорту: волейболу, баскетболу, настільного тенісу.

Під час використання методів оволодіння рухами як загалом, так i частинами належну увагу приділено добору підвідних та імітаційних вправ, що в подальшому зумовило опанування спортивної техніки шляхом планового освоєння найпростіших рухових дій.

Ураховуючи все вищесказане, у програмі підібрано види спорту так, щоб вони відповідали спортивним уподобанням студенток. Реалізацію авторської програми проведено у три етапи (табл. 1).

Таблиця 1

Етапи реалізації програми розвитку рухових якостей студенток закладів вищої освіти

\begin{tabular}{|c|c|c|c|c|}
\hline Етапи & $\begin{array}{c}\text { Термін } \\
\text { навчання }\end{array}$ & Види спорту & $\begin{array}{c}3 Ф П \\
(\%)\end{array}$ & $\begin{array}{c}\text { СФП } \\
(\%)\end{array}$ \\
\hline \multicolumn{5}{|c|}{ I курс } \\
\hline Перший & II семестр & $\begin{array}{c}\text { волейбол, настільний } \\
\text { теніс }\end{array}$ & 80 & 20 \\
\hline \multicolumn{5}{|c|}{ II курс } \\
\hline Другий & III семестр & $\begin{array}{c}\text { баскетбол, } \\
\text { настільний теніс }\end{array}$ & 70 & 30 \\
\hline Третій & IV семестр & $\begin{array}{c}\text { волейбол, настільний } \\
\text { теніс, баскетбол }\end{array}$ & 65 & 35 \\
\hline
\end{tabular}

На першому етапі у другому семестрі більшу увагу було сконцентровано на формуванні рухового потенціалу студенток, який сприяв ефективному засвоєнню та вдосконаленню технічних елементів конкретного виду спорту - волейболу й настільного тенісу. Як на початку цього етапу, так і в кінці основне місце займали загальна й допоміжна підготовка з використанням вправ з обраних видів спорту; 
застосовано засоби підвищення функціонального потенціалу організму в незначних обсягах. Завдання першого етапу реалізації методики такі:

- удосконалення стану розвитку недостатньо розвинутих фізичних якостей;

- активізація функціональних можливостей організму;

- розширення переліку рухових дій і засвоєних елементів техніки обраного виду спорту.

Навантаження в розділі «Спеціальна фізична підготовка» характеризувалося збільшенням кількості спеціально-підготовчих i змагальних вправ, обсягу навантажень, водночас незначно зростала інтенсивність виконання вправ i заняття загалом. ЧСС під час виконання вправ досягала 165-175 уд./хв.; відпочинок між підходами активний, відновлення ЧСС - до 90-100 уд./хв. Кількість підходів для виконання вправ поступово збільшувалася від 4 до 6 за незмінної кількості вправ. Для цього етапу характерними були змінний, повторний та інтервальний методи.

На другому етапі реалізації методики заняття були спрямовані на вдосконалення фізичних якостей; вони мали відносно великий обсяг роботи та значне навантаження.

На цьому етапі вирішували основні завдання інтегральної підготовки; СФП грунтувалася переважно на різноманітних спортивних елементах, а iï сумарна частка становила $30 \%$; частка ЗФП залишалася високою і становила 70\% від загальної структури.

До завдань другого етапу реалізації методики додали:

- розвиток фізичних якостей;

- активізацію функціональних можливостей організму;

- розширення арсеналу рухових дій;

- виховання вольових якостей.

Другий етап реалізації методики передбачав збільшення обсягу змагальних вправ, частка яких становила 20-30\%; питому вагу заняття становили загальнопідготовчі вправи - 50-60\%; це створювало передумови для успішного використання спеціалізованої фізичної підготовки.

Збільшилася кількість підходів у вправах порівняно з попередніми етапами (6-8), збільшилася кількість вправ, але подовжилася тривалість відпочинку між підходами, яка тривала до відновлення ЧСС до рівня 130-140 уд./хв. Особливістю цього етапу стало зростання частки змагальних методів. Тому інтенсивність виконання вправ зростала і переважно перебувала на рівні вище 130 середнього за ЧСС 170-175 уд./хв. На цьому етапі продовжує варіювати інтервальний метод із залученням змагального.

Третій етап реалізації методики був спрямований на вдосконалення й урізноманітнення арсеналу рухових дій і навичок, що відбувалося на 
основі високого рівня загальної фізичної підготовленості, досягнутого на попередніх етапах.

Незважаючи на значну спеціалізовану підготовку студенток на третьому етапі, частка якої становила $35 \%$ від усієї структури, увага значною мірою приділялася загальній фізичній підготовці, частка якої в цей період занять становила $65 \%$. До завдань третього етапу реалізації авторської програми долучили:

- підвищення стійкості організму до чинників, які негативно впливають на організм;

- розвиток умінь застосовувати фізичні вправи для підвищення працездатності у процесі професійної діяльності.

Третій етап підготовки вирізнявся з-поміж інших збільшенням кількості й інтенсивності спеціальних вправ (змагальних), частка яких становила $30 \%$, загальнопідготовчі вправи - $50 \%$, решта - допоміжні та напівспеціальні вправи; він передбачав вузькоспеціалізовану підготовку 3 використанням значних навантажень - до $70 \%$ від індивідуального максимуму. ЧСС під час виконання вправ могла досягати 175 уд./хв.; відпочинок між підходами був активний і тривав до відновлення ЧСС до 140 уд./хв. Кількість підходів у вправах порівняно із третім етапом зросла на 2 (тобто їх стало 8-10). На цьому етапі доцільними будуть інтервальний та змагальний методи.

Дослідження показників фізичного здоров'я студенток виявило, що впровадження програми занять на основі використання спортивних ігор мало більш позитивний вплив у студенток експериментальної групи порівняно зі студентками контрольної групи (табл. 2).

Таблиця 2

Порівняльна характеристика показників рівня соматичного здоров'я студенток у процесі педагогічного дослідження

\begin{tabular}{|c|c|c|c|c|c|c|c|c|}
\hline Група & $\begin{array}{c}\text { час } \\
\text { проведення }\end{array}$ & $\begin{array}{l}\text { Масовий } \\
\text { 1ндекс }\end{array}$ & $\begin{array}{l}\text { Жит гсвий } \\
\text { Нндекс }\end{array}$ & $\begin{array}{c}\text { Си.ловий } \\
\text { індекс }\end{array}$ & $\begin{array}{c}\text { Гндекс } \\
\text { Робіненона }\end{array}$ & 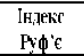 & IC3 & Рівень С 3 \\
\hline \multirow{4}{*}{$K(n=23)$} & Io & $\begin{array}{c}-0,65 \pm \\
0.18\end{array}$ & $1.55=(1.18$ & $2,(15+1), 38$ & $1,3+0,13$ & $\begin{array}{c}-0,2 \pm \\
0,34 \\
\end{array}$ & $4.05+0.18$ & нндчс серсаньосо \\
\hline & Після & $\begin{array}{c}-0,55 \pm \\
0,17\end{array}$ & $1,7=0,22$ & $2,1=0,38$ & $1,3 \pm 0,13$ & $\begin{array}{c}-10,2 \pm \\
0,34\end{array}$ & $4,35 \pm 0,27$ & наздек серелнього \\
\hline & t ирет. & 1.000 & $1,1+13$ & 1,000 & (i).(ii) & 0.00 & 1,552 & 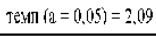 \\
\hline & 3міния \% & $18.18 \%$ & $8,82 \%$ & $2,380^{\circ}$ & $0.61 \% \%$ & $0,6(10 \%)$ & $7.41 \%$ & \\
\hline \multirow{4}{*}{$\operatorname{Sin}(n=23)$} & Ino & $\begin{array}{l}0.68 \pm \\
0,17\end{array}$ & $1,17=0,28$ & $0,68=0,1$ & $1.37 \pm 0.11$ & $1,05 \pm 0,4$ & $3.89 \pm(1.2$ & ннжие серелньиго \\
\hline & Після & $\begin{array}{c}-0.21 \pm \\
0.18\end{array}$ & $2,05=0.3$ & $1.89 \pm 0.33$ & $1.37 \pm 0.11$ & $1.05 \pm 0.4$ & $6.16 \pm 0.37$ & середызї \\
\hline & t крет. & 3,375 & 4,158 & 4,463 & 0,000 & 0,00 & 5,245 & $\operatorname{Tem}(\mathrm{a}=0,0,5)=2.1$ \\
\hline & Зміни \% & $30.88 \%$ & $28,290 \%$ & $64,02 \%$ & $0,00 \%$ & $0,00 \%$ & $36,85 \%$ & \\
\hline
\end{tabular}


Виявлено, що показники рівня соматичного здоров'я студенток контрольної групи не мали значних змін та відповідали рівню нижче середнього (p < 0,05). На початку формувального експерименту (лютий 2018 р.) індекс соматичного здоров’я студенток КГ дорівнював 4,05 \pm 0,18 бали.

Наприкінці основного дослідження (жовтень 2018 р.) індекс соматичного здоров'я студенток КГ становив 4,35 $\pm 0,27$ бали. Відсоткова різниця покращень за окремими значеннями показників рівня соматичного здоров'я у студенток КГ мала незначні зміни порівняно зі студентками експериментальної групи (p > 0,05) i становила приблизно 7,41\%.

Рівень соматичного здоров'я студенток експериментальної групи мав кращі показники і вірогідно підвищився $(\mathrm{p}<0,05)$, на відміну від показників студенток контрольної групи, які займалися за розробленою програмою.

Так, в експериментальній групі студенток індекс соматичного здоров'я на початку експерименту становив $3,89 \pm 0,2$ бали, а в кінці $6,16 \pm 0,37$ бали.

Аналіз показників життєвого індексу (далі - ЖІ) на початку експерименту показав, що: у студенток ЕГ (n = 23) індекс становив 1,47 $\pm 0,28$ бал. Після впроваджених експериментальних заходів показники у студенток ЕГ підвищилися на 28,29\% та становлять $2,05 \pm 0,3$ бали.

Аналіз отриманих даних за індексом Руф'є виявив більш позитивні зміни у студенток експериментальної групи $(\mathrm{p}<0,05)$. Тоді як у студенток контрольної групи значних змін ми не спостерігали (p > 0,05).

Дослідження індексу зросту-маси (масовий індекс) як важливого показника рівня соматичного здоров'я студенток виявило статистично вірогідні зміни у студенток експериментальної групи ( $<0,05)$.

Як видно 3 таблиці 2, середній показник масового індексу в ЕГ становив - 0,68 $\pm 0,17$ балів, наприкінці експерименту вінзріс до показника 0,21 $\pm 0,18$, покращення у відсотках відбулося на 30,88\%. Покращення показників масового індексу відбулося завдяки нормалізації маси тіла у студенток експериментальної групи. Масовий індекс студенток контрольної групи в кінці нашого дослідження також мав позитивні зміни $(18,18 \%)$, але порівняно зі студентками експериментальної групи вони були незначні $(\mathrm{p}>0,05)$.

Результати показника силового індексу виявили статистично вірогідні зміни у студенток експериментальної групи $(\mathrm{p}<0,001)$. Даний показник збільшився на $64,02 \%$. Контрольна група студенток, у відсотковому відношенні, показала менш значне покращення - 2,38\% ( $\mathrm{p}>0,05)$.

Проаналізовані нами показники індексу Робінсона у студенток експериментальної $(\mathrm{n}=23)$ та контрольної $(\mathrm{n}=23)$ груп на початку дослідження виявили, що даний показник не мав значної різниці у студенток обох груп. У кінці педагогічного експерименту показник 
індексу Робінсона підвищився в експериментальній групі студенток на $9,7 \%$ і становив $1,37 \pm 0,11$ ( $\mathrm{p}<0,05)$.

Показники у студенток контрольної групи залишилися 3 незначними змінами $(\mathrm{p}>0,05)$. До початку експерименту показники індексу Робінсона становили $1,30 \pm 0,13$, а в кінці експерименту показники не мали значних змін.

Отже, отримані нами результати дослідження рівня соматичного здоров'я студенток свідчать про високу ефективність запропонованих методичних заходів.

У результаті проведеного аналізу показників рівня сформованості рухових здібностей студенток нами з'ясовано, що показники обох досліджуваних груп до початку педагогічного експерименту відповідають низькому рівню. Контрольна й експериментальна групи студенток були сформовані таким чином, що за рівнем фізичної підготовленості вони не мали вірогідної різниці.

Рівень сформованості рухових здібностей і фізичних якостей визначався за такими тестами:

- тест на визначення рівня розвитку швидкості у вправі «Біг 100 м»;

- «Човниковий біг 10 х 5 м» на визначення рівня розвитку витривалості;

- тест на визначення рівня розвитку силових здібностей (згинання й розгинання рук в упорі лежачи);

- тест для оцінювання здібності до гнучкості (нахил уперед із положення сидячи);

- тест для оцінювання швидкісно-силових здібностей (стрибок у довжину з місця).

В обраному нами виді тестів ми керувалися загальними положеннями, опублікованими у працях провідних фахівців. ${ }^{11}$

Аналіз результатів показників рівня сформованості рухових якостей представлений у таблиці 3.

Під час виконання тесту «Біг 100 м», на етапі початкового тестування показники студенток, які виконують тест на високому рівні, становили $9,34 \%$ у КГ, $8,18 \%$ в ЕГ.

Після впровадження програми спостерігається позитивна динаміка у студенток ЕГ, ці показники становили $8,72 \%$, у контрольній групі студенток - 9,16\%.

Отже, в ЕГ приріст становив майже $11,9 \%$, у КГ - 4,17\%.

Під час виконання тесту «Нахил тулуба вперед» ми спостерігаємо зміни, які відбулися у студенток експериментальної та контрольної

${ }^{11}$ Круцевич Т., Воробйов М., Безверхня Г. Контроль у фізичному вихованні дітей, підлітків і молоді : навчальний посібник. Київ : Олімпійська література, 2011. 224 с. 
груп. Приріст у показниках становив 7,83\% у контрольній групі, $12,01 \%$ в експериментальній групі.

Таблиця 3

Результати тестування рівня розвитку рухових якостей студенток до та після експерименту

\begin{tabular}{|c|c|c|c|c|c|c|c|c|}
\hline Тести & $\begin{array}{c}\text { Гру } \\
\text { па }\end{array}$ & $\mathbf{N}$ & $\begin{array}{c}\text { До } \\
\text { eкспе } \\
\text { риме } \\
\text { нту } \\
\end{array}$ & $\underset{(\%)}{V}$ & $\begin{array}{c}\text { Після } \\
\text { експер } \\
\text { именту }\end{array}$ & $\mathrm{V}(\%)$ & $\begin{array}{c}\text { Приріс } \\
\text { T (\%) }\end{array}$ & $\mathbf{P}$ \\
\hline \multirow{2}{*}{ Біг 100 м } & К & 23 & $\begin{array}{l}16,25 \\
\pm 1,52\end{array}$ & 9,34 & $\begin{array}{c}15,6 \pm \\
1,43\end{array}$ & 9,16 & 4,17 & $>0,05$ \\
\hline & E & 23 & $\begin{array}{l}17,32 \\
\pm 1,42\end{array}$ & 8,18 & $\begin{array}{c}15,47 \pm \\
1,35\end{array}$ & 8,72 & 11,9 & $<0,001$ \\
\hline \multirow{2}{*}{$\begin{array}{c}\text { Нахил } \\
\text { тулуба } \\
\text { вперед, } \\
\text { см }\end{array}$} & K & 23 & $\begin{array}{l}13,92 \\
\pm 1,13 \\
\end{array}$ & 8,13 & $\begin{array}{c}15,01 \pm \\
1,15\end{array}$ & 7,66 & 7,83 & $<0,001$ \\
\hline & E & 23 & $\begin{array}{l}14,42 \\
\pm 1,54\end{array}$ & $\begin{array}{c}10,6 \\
8\end{array}$ & $\begin{array}{c}16,15 \pm \\
1,9\end{array}$ & 11,77 & 12,01 & $<0,001$ \\
\hline \multirow{2}{*}{$\begin{array}{c}\text { Стрибок у } \\
\text { довжину з } \\
\text { місця, см }\end{array}$} & K & 23 & $\begin{array}{c}168,7 \\
6 \pm \\
16,35 \\
\end{array}$ & 9,69 & $\begin{array}{r}169,57 \\
\pm 16,21 \\
\end{array}$ & 9,56 & 0,48 & $<0,001$ \\
\hline & E & 23 & $\begin{array}{c}171,2 \\
3 \pm \\
16,51 \\
\end{array}$ & 9,64 & $\begin{array}{c}173,98 \\
\pm 16,89 \\
\end{array}$ & 9,71 & 1,61 & $<0,001$ \\
\hline \multirow{2}{*}{$\begin{array}{l}\text { Згинання і } \\
\text { розгинання } \\
\text { рук в упорі } \\
\text { лежачи, раз }\end{array}$} & K & 23 & $\begin{array}{r}19,35 \\
\pm 1,79 \\
\end{array}$ & 9,23 & $\begin{array}{c}19,85 \pm \\
1,87 \\
\end{array}$ & 9,43 & 2,58 & $<0,001$ \\
\hline & E & 23 & $\begin{array}{r}18,79 \\
\pm 1,23\end{array}$ & 6,54 & $\begin{array}{c}20,58 \pm \\
1,54\end{array}$ & 7,48 & 9,52 & $<0,001$ \\
\hline \multirow{2}{*}{$\begin{array}{c}\text { Підйом } \\
\text { тулуба в сід } \\
\text { із положення } \\
\text { лежачи, раз }\end{array}$} & K & 23 & $\begin{array}{l}16,15 \\
\pm 1,95 \\
\end{array}$ & 12,1 & $\begin{array}{c}16,55 \pm \\
2,37\end{array}$ & 14,34 & 2,48 & $<0,05$ \\
\hline & E & 23 & $\begin{array}{c}16,42 \\
\pm 1,74\end{array}$ & $\begin{array}{c}10,6 \\
1\end{array}$ & $\begin{array}{c}18,26 \pm \\
1,59\end{array}$ & 8,72 & 11,22 & $<0,001$ \\
\hline \multirow{2}{*}{$\begin{array}{c}\text { Човниковий } \\
\text { біг } 10 \times 5 \text { м, с }\end{array}$} & К & 23 & $\begin{array}{r}19,33 \\
\pm 1,28 \\
\end{array}$ & 6,6 & $\begin{array}{c}19,18 \pm \\
1,42\end{array}$ & 7,38 & 0,81 & $>0,05$ \\
\hline & E & 23 & $\begin{array}{l}19,32 \\
\pm 1,06\end{array}$ & 5,49 & $\begin{array}{c}18,64 \pm \\
1,13\end{array}$ & 6,07 & 3,64 & $<0,001$ \\
\hline
\end{tabular}

Порівнюючи показники початкового тестування «Згинання i розгинання рук» із результатами тестів на заключному етапі дослідження, ми виявили, що жодна студентка як в ЕГ, так у КГ не залишилась на низькому рівні, а покращила свої результати. Показники у студенток КГ мали незначні зміни, порівняно зі студентками ЕГ ( $<<0,001)$.

Результати тестування «Вибухової сили» виявили позитивні зміни у студенток ЕГ $(\mathrm{p}<0,001)$. На початку педагогічного дослідження кількість студенток, які виконують тест на середньому рівні, в експериментальній групі становила 47,4\%. 
Повторне тестування виявило зменшення кількості студенток iз середнім рівнем на $10,6 \%$, завдяки цим змінам збільшилась кількість студенток із показником вище середнього (10,5\%), показники студенток контрольної групи також мали позитивні зміни, але лише на 5\%.

На початку нашого дослідження 5,3\% студентків ЕГ мали показники тесту «Човниковий біг 5 х 10 м», які відповідають низькому рівню. У КГ за даним видом тесту мали 5\% за результатом, який відповідає низькому рівню, згідно 3 перцентильною оціночною шкалою.

Після впровадження розроблених експериментальних заходів нами зафіксовано статистично достовірне покращення показників в ЕГ студенток на 3,64\%.

У тесті «Підйом тулуба в сід» у студенток ЕГ ми виявили позитивну динаміку на різних рівнях виконання. Зменшився відсоток студенток ЕГ, які виконували тест на низькому та нижче середнього рівнях, i збільшився відсоток тих, хто виконує тест на рівні середньому та вище середнього $(\mathrm{p}<0,001)$.

У КГ 5\% мають показники, що відповідають низькому рівню, 10\% відповідають рівню нижче середнього.

Аналіз отриманих результатів виявив тенденцію до збільшення кількості студенток обох груп, які виконували тест «Підйом тулуба в сід» на високому рівні.

У студенток ЕГ спостерігалося покращення на $11,22 \%$, у студенток КГ - на 2,48\% $(\mathrm{p}<0,05)$.

Підсумкова оцінка отриманих результатів дослідження фізичної підготовленості студенток дозволяє зробити висновок про ефективність застосування програми для розвитку рухових якостей у процесі секційних занять студенток.

\section{ВИСНОВКИ}

Аналіз сучасної наукової літератури виявив, що існуюча система фізичного виховання в закладах вищої освіти не забезпечує усвідомлену активну рухову діяльність студенток, цілеспрямовану й відповідну їхнім індивідуальним особливостям. Основні ії недоліки такі: недостатність теоретичної розробленості, слабка матеріальна база, низький рівень вмотивованості студентської молоді до занять фізичними вправами, що знижує можливості існуючої системи 
фізичного виховання та професійно-прикладної фізичної підготовки впливати на зміцнення здоров'я студентської молоді як майбутнього нашої країни.

Результати соціологічного дослідження дозволили з'ясувати мотиви та пріоритети студенток щодо занять фізичними вправами. Отримані данні анкетування стали підгрунтям для подальшої розробки програми занять із використанням засобів спортивних ігор для розвитку рухових якостей студенток.

Порівняльний експеримент, спрямований на визначення ефективності занять за розробленою нами програмою, дозволив виявити позитивний достовірний приріст практично за всіма досліджуваними показниками у студенток експериментальної групи. Нами встановлено, що програма занять із використанням спортивних ігор мала найбільший вплив на показники функціонального стану хребта (сила і витривалість м'язів, рухливість суглобів), на дихальну систему і на психофізіологічні показники студенток.

Аналіз отриманих результатів дослідження розвитку рухових якостей студенток дозволяє зробити висновок про ефективність застосування програми занять із використанням спортивних ігор у позанавчальному процесі закладів вищої освіти, що виявляється в покращенні досліджуваних показників.

Після впровадження педагогічного експерименту нами зазначені статистично вірогідні зміни у студенток експериментальної групи на $11,22 \%$, (p < 0,01), порівняно 3 контрольною групою, де приріст становив $2,48 \%(\mathrm{p}<0,05)$.

Отримані результати потребують подальшого теоретичного й експериментального дослідження.

\section{АНОТАЦІЯ}

Проблема збереження і зміцнення здоров'я студентської молоді актуальне питанням сьогодення. Умови навчання в закладах вищої освіти висувають завищені вимоги, які спричиняють погіршення здоров'я студенток. Останні наукові дослідження свідчать, що активні заняття фізичними вправами та спортом відіграють важливу роль у відновленні та покращенні здоров'я.

Для стимулювання зацікавленості студенток до занять різними видами фізичної активності необхідно використовувати сучасні 
методики та технології, які спрямовані на формування інтересу до занять фізичними вправами.

У статті представлені результати дослідження розвитку рухових якостей студенток закладів вищої освіти засобами спортивних ігор у процесі неформальної фізкультурної освіти.

Результати дослідження показують ефективність застосування програми розвитку рухових якостей студенток закладів вищої освіти. Після проведення педагогічного експерименту спостерігалися статистично вірогідні зміни у студенток експериментальної групи порівняно з контрольною группою.

\section{ЛIТЕРАТУРА}

1. Апанасенко Г., Науменко Р. Экспресс-оценка уровня физического развития. Теория и практика физической культуры. 1988. № 4. С. 27-29.

2. Вихляєв Ю. Інноваційні технології фізичного виховання студентів : навчальний посібник. Київ : КПІ ім. Ігоря Сікорського, 2018. $543 \mathrm{c}$.

3. Грибан Г. Формування здорового способу життя у студентів у навчальному процесі з фізичного виховання. Вісник Чернігівського національного педагогічного університету імені Т.Г. Шевченка. 2014. Вип. 118. Т. III. С. 97-101.

3. Захаріна Е. Формування мотивації до рухової активності у процесі фізичного виховання студентів вищих навчальних закладів : автореф. дис. ... канд. наук з фіз. вих. і спорту: 24.00.02. Київ, 2008. 27 с.

4. Ібрагімова Л. Стратегічні напрямки вдосконалення системи фізичного виховання студентів вузів. Молодий вчений. 2016. № 3. C. 611-615.

5. Іваненко T. Формування позитивно ціннісного ставлення студенток університету до оздоровчої діяльності : автореф. дис. ... канд. пед. наук: 13.00.07. Київ, 2011. 16 с.

6. Кашуба В., Денисова Л., Усиченко В. Комп'ютерна техніка та методи математичної статистики : навчальний посібник. МОНУ, НУФВСУ. Київ, 2015. 212 с.

7. Кляп М. Інноваційні методи навчання у ВНЗ як інструмент інтернаціоналізації вищої освіти України. Вища освіта України, 2015. № 4. C. 45-53. 
8. Куртова Г., Рибалко П., Красілов А. Педагогічні умови формування здоров'язбережувальної компетентності фахівців аграрного сектора у процесі фізичного виховання. Педагогічні науки: теорія, історія, інноваційні технології. 2018. № 4. С. 100-111.

9. Круцевич Т., Воробйов М., Безверхня Г. Контроль у фізичному вихованні дітей, підлітків і молоді : навчальний посібник. Київ : Олімпійська література, 2011. 224 с.

10. Методика управління фізкультурно-оздоровчою діяльністю в сучасних закладах середньої освіти / М. Лянной та ін. Педагогічні науки: теорія, історія, інноваційні технології : науковий журнал. Суми, 2019. № 4 (88). С. 280-289.

11. Матлаш В., Рибалко П., Харченко С. Динаміка показників психологічної підготовки студентів аграрного університету під впливом секційних занять 3 шахів. Вісник Чернігівського національного педагогічного університету імені Т.Г. Шевченка. Серія «Педагогічні науки». 2016.

12. Матлаш В., Рибалко П., Харченко С. Вдосконалення технікотактичних дій студенток першого курсу аграрного університету на секційних заняттях з волейболу. Фізична культура, спорт та здоров'я нащиї : наукове видання. Вип. 1 / гол. ред. В. Костюкевич ; Вінницький державний педагогічний університет імені Михайла Коцюбинського ; Житомирський державний університет імені Івана Франка. Вінниця : ТОВ « Планер», 2017.

13. Мартинюк О. Печена В., Кравченко К. Аналіз різноманітних методик оцінки рівня фізичного здоров'я студентської молоді. Фізична культура, спорт та здоров'я наиії : збірник наукових праць / гол. ред. В. Костюкевич. Вінницький державний педагогічний університет імені Михайла Коцюбинського. Вінниця : Платер, 2014. № 1. С. 183-189.

14. Петренко О. Вивчення ставлення студенток економічних спеціальностей до занять з фізичного виховання. Молода спортивна наука Украӥни. 2014. Т. 2. С. 98-101.

15. Рибалко П. Особливості розвитку, формуванняі збереження здоров'я молоді в сучасних умовах. Вісник Чернігівського державного педагогічного університету ім. Т.Г. Шевченка. 2011. Вип. 91. Т. 1. 536 c. C. $392-394$.

16. Рибалко П. Сучасні технології збереження та відновлення здоров'я молоді в діяльності фахівця 3 фізичної культури. Вісник 
Чернігівського національного педагогічного університету імені Т.Г. Шевченка. Серія «Педагогічні науки». 2016. Вип. 136. С. 181-184.

17. Рибалко П., Самохвалова І., Мелюшкіна В. Рівень групової згуртованості спортивно-ігрових студентських команд аграрного університету. Вісник Чернігівського національного педагогічного університету імені Т.Г. Шевченка / гол. ред. М. Носко. 2016.

18. Рибалко П., Харченко С., Матлаш В. Професійно-прикладна фізична підготовка студенток аграрного вузу, що займаються в секції 3 футболу. Вісник Чернігівського національного педагогічного університету імені Т.Г. Шевченка. 2017. Вип. 149. С. 212-215.

19. Рибалко П., Гриб Т., Клименченко Т. Проблеми і шляхи підвищення ефективності фізичного виховання у вищому навчальному закладі нефізкультурного профілю. Фізична культура, спорт та здоров'я нації : наукове видання. Вип. 1 / гол. ред. В. Костюкевич ; Вінницький державний педагогічний університет імені Михайла Коцюбинського ; Житомирський державний університет імені Івана Франка. Вінниця : ТОВ « Планер», 2017. С. 217-221.

20. Рибалко П. Керівні підходи і принципи у підготовці вчителів фізичної культури до оздоровчо-спортивної діяльності. Гуманізація навчально-виховного процесу : збірник наукових праць. Державний вищий навчальний заклад «Донбаський державний педагогічний університет». 2019. № 4 (96). С. 66-77.

21. Савчук С. Аналіз стану соматичного здоров'я студентів вищого технічного навчального закладу. Фізичне виховання, спорт $i$ культура здоров'я у сучасному суспільстві : збірник наукових праць. Луцьк, 2011. № 3. С. 79-82.

22. Сабіров О. Здоров'я студента як національно-культурна цінність в освітньому євроінтеграційному просторі. Фізичне виховання, спорт $i$ культура здоров'я у сучасному суспільстві : збірник наукових праць. Луцьк, 2016. С. 16.

23. Самохвалова І., Мелюшкіна В., Рибалко П. Настільний теніс як засіб розвитку координаційних здібностей студентів аграрного університету. Вісник Чернігівського начіонального педагогічного університету імені Т.Г. Шевченка. Серія «Педагогічні науки». 2018. Вип. 151 (1). С. 133-136. 
24. Методика викладання навчальної дисципліни «Фізичне виховання» у закладі вищої освіти / Р. Харченко та ін. Педагогічні науки: теорія, історія, інновачійні технологї̈. 2019. № 5. С. 183-195.

25. Особливості методики розвитку фізичних якостей студентів неспортивних спеціальностей на заняттях фізичною культурою / О. Хоменко та ін. Педагогічні науки: теорія, історія, інноваиійні технології : науковий журнал. Суми, 2019. № 6 (90). С. 343-352.

\section{Information about the authors: Rybalko P. F.,}

Ph. D. in Pedagogic Sciences, Associate Professor, Associate Professor of the Department of Theory and Methods of Physical Culture Sumy Makarenko State Pedagogical University 87, Romenskaya str., Sumy, 40002, Ukraine ORCID ID: orcid.org/0000-0002-6460-4255

Samokhvalova I. I.,

$\mathrm{Ph}$. D. Student of the Department of Theory and Methods of Physical Education Sumy Makarenko State Pedagogical University 87, Romenskaya str., Sumy, 40002, Ukraine ORCID ID: orcid.org/0000-0001-7017-6915 